Archives of Agriculture and Environmental Science

\title{
Agronomic manipulation for adaptation of black rice cultivars in plain land environment to eliminate hidden hunger
}

\author{
Md. Rashedur Rahman ${ }^{1^{*}}$ (D) , Md. Parvez Anwar ${ }^{1}$ and Iffat Ara Mahzabin ${ }^{2}$ \\ ${ }^{1}$ Department of Agronomy, Bangladesh Agricultural University, Mymensingh - 2202, BANGLADESH \\ ${ }^{2}$ Department of Agricultural Extension Education, Bangladesh Agricultural University, Mymensingh - 2202, BANGLADESH \\ *Corresponding author's E-mail: rashedagron@bau.edu.bd
}

\section{ARTICLE HISTORY}

Received: 25 May 2019

Revised received: 03 June 2019

Accepted: 05 June 2019

\section{Keywords}

Agronomic management

Black rice cultivars

Hidden hunger

Plain land

\begin{abstract}
Two field experiemtns were conducted at the Agronomy Field Laboratory, Bangladesh Agricultural University, Mymensingh during the period from July 2016 to December 2016 to study the effect of cultivars, date of transplanting and fertilizer dose on the yield and quality of few hilly black rice cultivars. The experiment one consisted of two factors. Factor A: Varieties, viz., i) Galong se and ii) Gelong ni and Factor B: Planting date, viz., i) July 20, ii) August 5, iii) August 20, iv) September 5, v) September 20 and vi) October 5. The experiment two also consisted with two factors. Factor A: varieties, viz., i) Kongnam ene ii) Gelong se and iii) Nazirshail rice and Factor B: Fertilizer management viz., i) No fertilizer ii) $50 \%$ of recommended dose (RD) of fertilizers of a local aman rice variety, iii) $75 \%$ of RD of fertilizers of a local aman rice variety, iv) $100 \%$ of RD of fertilizers of a local aman rice variety, v) $125 \%$ of RD of fertilizers of a local aman rice variety and vi) $150 \%$ of RD of fertilizers of a local aman rice variety. Results revealed that among varieties, the black rice cultivar Gelong se was best grain yielding potential variety than three other rice varieties, of which two are black rice cultivars (Kongnam ene and Gelong ne) and another one is plain land white rice cultivar (Nizershail). Regarding time of transplanting it has been found that all the varieties gave higher yield when they were transplanted either on July 20 or August 05. The worst transplanting time was October 5 when lowest grain yield was obtained. From the nutritional view point, it has been found that all the three black rice cultivars got higher crude protein (\%), crude fibre (\%), ash (\%), crude fat (\%), Fe (ppm) and $\mathrm{Zn}(\mathrm{ppm})$ content over white rice cultivar. Therefore, it can be concluded that black rice could be incorporated in human diet and it would be a way of eliminating hidden hunger.
\end{abstract}

(C)2019 Agriculture and Environmental Science Academy

Citation of this article: Rahman, M.R., Anwar, M.P. and Mahzabin, I.A. (2019). Agronomic manipulation for adaptation of black rice cultivars in plain land environment to eliminate hidden hunger. Archives of Agriculture and Environmental Science, 4(2): 198-205, https://dx.doi.org/10.26832/24566632.2019.0402011

\section{INTRODUCTION}

Rice is the staple food for Bangladeshi people. It is cultivated in $74.85 \%$ of our agricultural land (BBS, 2018). In Aus, Amon and Boro season 2134, 13656, 18014 thousand metric ton rice was estimated to be produced in 2017 from 2327, 13797, 11060 thousand acre land respectively (BBS, 2017). However, people of Bangladesh consume a lots of rice as staple food but this rice, the white rice, provides mainly carbohydrate to the people's diet and this rice is lack of other important essential nutrients for human health which ultimately enhance the hidden hunger of this mass people of Bangladesh. Hidden hunger is a chronic lack of vitamins and minerals that often has no visible warning signs, so that people who suffer from it may not even be aware of it. Its consequences are nevertheless disastrous: hidden hunger can lead to mental impairment, poor health and productivity, or even death. Black rice, a traditional rice cultivars, is being cultivating in the hilly area of Bangladesh especially in the Bandarban and Rangamati region, could be a potential way of eliminating the hidden hunger as it contains high amount of nutrients required for human body.

Black rice is a type of the rice species Oryza sativa L. which is 
glutinous, packed with high level of nutrients and mainly cultivated in Asia. The pericarp (outer part) of kernel of this rice colour is black due to a pigment known as anthocyanin, an antioxidant. Black rice is also known as purple rice, forbidden rice, heaven rice, imperial rice, king's rice and prized rice. Black rice is a whole grain and nowadays, whole grain is categorized as one of the potent functional food sources since it contains high amounts of phenolic compounds, especially anthocyanins in pericarp (Abdel-Aal et al., 2006, Ryu et al., 1998; Yawadio et al., 2007). This rice is supposed to enhance the longivity of life, hence it is also known as long life rice. Black rice extracts could scavenge superoxide anions more effectively than hydroxyl radicals (Nam et al., 2006). This rice has long been consumed in Korea, Japan and China (Ryu et al., 2000; Han et al., 2004). This rice includes several varieties with a long history of cultivation in Southeast Asian countries such as China, India and Thailand (Kong et al., 2008). There are more than 200 types of black rice varieties in the world. Only China is responsible for $62 \%$ of global production of black rice and it has developed more than 54 modern black rice varieties with high yield characteristics and multiple resistances. Thailand occupies the ninth position to black rice cultivation (Ichikawa et al., 2001; Sompong et al., 2011). Interest in black rice is indicated by the number of accessions held in germplasm collections, e.g. China-359, Sri Lanka50, Indonesia-42, India-30, the Philippines-25 and Bangladesh -24 (Chaudhary, 2003). Nutrients such as protein, minerals (Ca, $\mathrm{P}, \mathrm{Fe}$, and $\mathrm{Zn}$ ) and dietary fiber contents are higher in black rice compared to brown and white rice. Demand for this rice is growing fast in the USA and European countries due to its value as a healthy food and its attractive organic food color. Ichikawa et al. (2001) reported that black rice is efficient, and two fold stronger with respect to antioxidant activities of blueberries. Black rice is surely a special breed of rice that is cultivated on earth. This rice is getting popular in recent years because of its high nutritive value and antioxidative properties. In Bangladesh it known as "kalo dhaner chaal"(Black paddy's rice) and broadly used to make polao or rice based desserts. Black rice is a source of iron, vitamin E, and antioxidants. The bran hull (outermost layer) of black rice contains one of the highest levels of anthocyanins found in food (Yao et al., 2013).

Though the popularity of black rice and knowledge about its health benefits is growing in western nations including the US, it still remains much less popular than white and brown rice. As more people learn about black rice's benefits and demand it, black rice will probably become more widely available at larger chain supermarkets and restaurants. Today this type of rice is picking up popularity and popping up in more health food stores across the US, Australia, and Europe, as people discover the numerous health benefits that whole grain black rice has to offer. In Bangladesh, the black rice is being cultivating in the remote hilly areas including Bandarban district as shifting cultivation crop without any agronomic management practices and hence giving very low yield. Also the cultivation procedure of this black rice under plain land condition is still unknown in Bangladesh. Therefore, this study intends to explore the suitability of black rice cultivation under plain land condition to increase its productivity through different agronomic practices. This ultimately may eradicate the hidden hunger from the nation.

\section{MATERIALS AND METHODS}

\section{Description of experimental site}

The study was conducted at the Agronomy Field Laboratory, Bangladesh Agricultural University, Mymensingh from December 2015 to May 2016. The experimental site is located at $24^{\circ} 75^{\prime} \mathrm{N}$ latitude and $90^{\circ} 50^{\prime} \mathrm{E}$ longitude in the south-west part of Brahmaputra at an elevation of $18 \mathrm{~m}$ above the sea level. This site belongs to non-calcareous dark grey floodplain soil under the agroecological zone Old Brahmaputra Floodplain.

\section{Characteristics of test variety}

Kongnam ene, Gelong ni and Gelon se, are three hilly rice cultivars and a local rice cultivar named Nazirshail were used as the test crop in this experiment. The seeds of the three black rice varieties were collected from Bandarban hill district of Bangldesh. The plain land cultivar used in this experiment was Nizershail. The main characteristic features of the rice cultivars are discussed below:

Kongnam ene is a black rice variety which includes a long history of cultivation in Southeast Asian countries such as China, India and Thailand (Kong et al., 2008). The pericarp (outer part) of kernel of this rice color is black due to a pigment known as anthocyanin, an antioxidant. Brown rice has also many health benefits. It is a transplant aman rice cultivar and matures after 90 days after transplanting with average yield 3.0-3.5 $\mathrm{t} \mathrm{ha}^{-1}$. Life cycle of this variety ranges from 95-105 days, which however may vary due to changes in climatic condition. The plant height is $90-95 \mathrm{~cm}$ and the cultivar is of non-lodging type. It is somewhat resistant to pests and diseases and especially blast disease. Gelong ni and Gelong se are rice variety traditionally cultivated in hilly upland area. This rice varieties are short duration variety. It matures after 110-120 days of transplanting. Plant Height is higher than the other two varieties tested. So, the plant sometimes lodges before panicle matures. Plant height is usually around $120 \mathrm{~cm}$. The hull and bran around the kernel are brown in color Yield is about $4.1 \mathrm{t} \mathrm{ha}^{-1}$. Both these rice varieties are a good source of magnesium, phosphorus, selenium, thiamin, niacin and vitamin B6, and an excellent source of manganese, with 88 percent of our daily manganese in just one cup cooked. The morphological and nutritional characteristics are almost same for these two varieties except the thousand grain weight. The thousand grain weight of variety Gelong ni is little higher than that of Gelong se.

Nazirshail is a transplant aman rice. It is grown locally to consume as white rice. Plant height is usually about $150 \mathrm{~cm}$. No of tillers is 6-7. Yield is about 3.5-4.o $\mathrm{t} \mathrm{ha}^{-1}$. It is a long duration variety (135-145 days). This variety is resistant to leaf blight and sheath rot diseases. This rice variety can cope with water logging condition. 
Preparation of the experimental land and raising of crop

The land was first opened with a tractor drawn disc plough on 01 May 2016. After two days, the land was irrigated slightly and subsequent ploughings and cross ploughings were given and leveled by laddering. The field layout was made on 01 July 2016 according to experimental specification immediately after final land preparation. Weeds and stubbles were cleared off from individual plots and finally plots were leveled properly by wooden ladder so that no water pocket could remain in the field. Twenty eight days old seedlings were carefully uprooted from nursery bed and transplanted in the plots according to the treatments maintaining a spacing of $25 \mathrm{~cm} \times 15 \mathrm{~cm}$. Three healthy seedlings were transplanted in each hill. Various intercultural operations viz., irrigation, weeding, disease and pest management etc. were done as and when necessary to ensure and maintain the favorable condition for normal plant growth and development of crop.

\section{Layout of the experiment}

There were two experiments conducted at the same time. The first experiment consisted of two factors such as Factor A: black rice varieties, viz., i) Galong se and ii) Gelong ni and Factor B: Planting date, viz., i) July 20, ii) August 5, iii) August 20, iv) September 5, v) September 20 and vi) October 5. The second experiment consisted of also with two factors. Factor A: black rice varieties, viz., i) Kongnam ene ii) Gelong se and iii) Nazirshail rice and Factor B: Fertilizer management viz., i) No fertilizer ii) $50 \%$ of recommended dose (RD) of fertilizers of a local aman rice variety, iii) $75 \%$ of $\mathrm{RD}$ of fertilizers of a local aman rice variety, iv) $100 \%$ of RD of fertilizers of a local aman rice variety, v) $125 \%$ of RD of fertilizers of a local aman rice variety and vi) $150 \%$ of RD of fertilizers of a local aman rice variety.

The first experiment was laid out in Randomized Complete Block Design (RCBD) with three replications. Thus total number of plots were $36(2 \times 6 \times 3)$. Each plot size was $10 \mathrm{~m}^{2}(4 \mathrm{~m} \times 2.5 \mathrm{~m})$. The unit plots were uniformly fertilized with, urea, triple superphosphate, muriate of potash and gypsum according to the recommended dose of any local aman rice variety. All intercultural operations were done as and when necessary. The second experiment was also laid out in a Randomized Complete Block Design (RCBD) with three replications. Thus total number of plots were $(3 \times 6 \times 3)=54$. Each plot size was $10 \mathrm{~m}^{2}(4 \mathrm{~m} \times 2.5 \mathrm{~m})$. The unit plots were fertilized with urea, triple super phosphate, muriate of potash and gypsum according to the treatments. All intercultural operations were done as and when necessary.

\section{Observation and data collection}

The crop was harvested at full maturity. The date of harvesting was confirmed when $90 \%$ of the grain became golden yellow in color. Five hills (excluding the border hills) were selected randomly from each individual plot and uprooted before harvesting for recording data., After sampling the whole crops were harvested in each plot. The harvested crop of each plot was separately bundled properly tagged and brought to the threshing floor for threshing. The harvested crop were threshed manually. The grains were cleaned and dried to a moisture content of $14 \%$. Straws were sun dried properly. Final grain and straw yields plot $^{-1}$ were recorded and converted to ton $\mathrm{ha}^{-1}$.

\section{Nutritional analysis of grain}

To get the information regarding nutrient contents of the rice varieties the grain was chemically analyzed through the standard process of chemical analysis. The nutrient elements included soluble $\mathrm{CHO}(\%)$, crude protein (\%), crude fibre (\%), crude fat (\%), ash (\%), Fe (ppm) and Zn (ppm).

\section{Statistical analysis of data}

Data were compiled and tabulated in proper form for statistical analysis. The recorded data were statistically analyzed to find out the significance of variation resulting from the experimental treatments. All the collected data were analyzed using the statistical software R.

\section{RESULTS AND DISCUSSION}

Experiment one (Optimizing planting time of two black rice cultivars)

\section{Crop characteristics}

All the crop characters like plant height, number of total tillers and panicle length were significantly affected by date of planting and varieties with $5 \%$ level of significance (Table 1 ). The table shows that tallest plant $(131.03 \mathrm{~cm})$ was obtained when the crop was transplanted at July 20 which was statistically at par with $131.00 \mathrm{~cm}$ when the crop was transplanted at August 5. Considering the varietal effect, tallest plant (108.91) was obtained from black rice cultivar Gelong ni (Table 2). Interaction effect on plant height was also significant at $5 \%$ level of significance and it was observed that tallest plant height $(133.87 \mathrm{~cm})$ was obtained with the variety Gelong ni (Table 3) when it was transplanted on July 20 which was statistically similar $(130.93 \mathrm{~cm})$ with that of same variety transplanted at August 5, the cultivar Gelong se when transplanted both on July 20 and August 05.

In case of total tillers, varieties did not exert any significant difference on total tillers. Highest number of total tillers (8.37) was found when the rice plant was transplanted at August 5. Considering interaction, highest total tillers (9.00) was observed when the variety Gelong se was transplanted on August 05.

Panicle length was significantly affected by date of planting and interaction between date of planting and varieties with $5 \%$ level of significance. Varieties did not exert any significant difference on panicle length. Statistically the longest panicle $(23.52 \mathrm{~cm})$ was found when the rice plant was transplanted on August 5 which was statistically similar when transplanted on July 20. Considering interaction, longest panicle was observed in case both of the varieties $(23.56 \mathrm{~cm}$ in Gelong ni and $23.49 \mathrm{~cm}$ in Gelong se) when they were transplanted on August 05. All the interaction effects have been presented in Table 3. 
Table 1. Effect of planting time on crop characters of black rice varieties in plain land environment.

\begin{tabular}{|c|c|c|c|c|c|c|c|c|}
\hline Planting date & $\begin{array}{c}\text { Plant } \\
\text { height }(\mathrm{cm})\end{array}$ & $\begin{array}{l}\text { No. of total } \\
\text { tillers hill }^{-1}\end{array}$ & $\begin{array}{c}\text { No. of } \\
\text { effective } \\
\text { tillers hill }^{-1}\end{array}$ & $\begin{array}{l}\text { Panicle } \\
\text { length } \\
\text { (cm) }\end{array}$ & $\begin{array}{c}\text { No. of } \\
\text { grains } \\
\text { panicle }^{-1}\end{array}$ & $\begin{array}{l}1000 \text { grain } \\
\text { weight }(g)\end{array}$ & $\begin{array}{l}\text { Grain } \\
\text { yield } \\
\left(\mathrm{t} \mathrm{ha}^{-1}\right)\end{array}$ & $\begin{array}{c}\text { Straw } \\
\text { yield } \\
\left(\mathrm{t} \mathrm{ha}^{-1}\right)\end{array}$ \\
\hline July 20 & $131.03 a$ & $6.90 \mathrm{~b}$ & $5.73 b$ & $23.33 a$ & $142.89 a$ & $16.82 a$ & $3.7 a$ & $3.5 \mathrm{a}$ \\
\hline August 5 & $131.00 \mathrm{a}$ & $8.37 \mathrm{a}$ & $6.87 a$ & $23.52 a$ & $129.81 b$ & $16.80 \mathrm{a}$ & $4.0 \mathrm{a}$ & $2.7 \mathrm{~b}$ \\
\hline August 20 & $113.27 b$ & $6.27 \mathrm{~b}$ & $5.23 \mathrm{~b}$ & $22.41 b$ & $101.91 \mathrm{c}$ & $16.79 a$ & $2.41 \mathrm{~b}$ & $2.2 \mathrm{~b}$ \\
\hline September 5 & $92.03 c$ & $5.63 \mathrm{bc}$ & $4.40 \mathrm{c}$ & $19.70 c$ & $73.51 d$ & $16.58 a$ & $1.45 \mathrm{c}$ & $4.0 \mathrm{a}$ \\
\hline September 20 & $82.67 d$ & $6.77 b$ & $4.23 c$ & $19.24 c$ & $60.39 e$ & $16.39 a$ & $1.11 \mathrm{c}$ & $2.4 \mathrm{~b}$ \\
\hline October 5 & $75.34 \mathrm{e}$ & $4.50 \mathrm{c}$ & $3.66 \mathrm{c}$ & $17.87 d$ & $42.68 \mathrm{f}$ & $12.04 \mathrm{~b}$ & $0.52 \mathrm{~d}$ & $2.2 \mathrm{~b}$ \\
\hline Level of sig. & $*$ & $*$ & $*$ & $*$ & $*$ & $*$ & $*$ & $*$ \\
\hline
\end{tabular}

In a column, figures with same letter or without letter do not differ significantly whereas figures with dissimilar letters differ significantly as per DMRT; ${ }^{*}=$ Significant at $5 \%{ }^{* *}=$ Significant at $1 \% \quad$ NS=Non-significant.

Table 2. Effect of variety on crop characters of black rice varieties in plain land environment.

\begin{tabular}{|c|c|c|c|c|c|c|c|c|}
\hline Varieties & $\begin{array}{l}\text { Plant height } \\
(\mathrm{cm})\end{array}$ & $\begin{array}{l}\text { No. of total } \\
\text { tillers hill }^{-1}\end{array}$ & $\begin{array}{c}\text { No. of } \\
\text { effective } \\
\text { tillers hill }^{-1}\end{array}$ & $\begin{array}{l}\text { Panicle } \\
\text { length } \\
\text { (cm) }\end{array}$ & $\begin{array}{l}\text { No. of } \\
\text { grains } \\
\text { panicle }^{-1}\end{array}$ & $\begin{array}{c}1000 \\
\text { grain } \\
\text { weight (g) }\end{array}$ & $\begin{array}{l}\text { Grain } \\
\text { yield } \\
\left(\mathrm{t} \mathrm{ha}^{-1}\right)\end{array}$ & $\begin{array}{c}\text { Straw } \\
\text { yield } \\
\left(\mathrm{t} \mathrm{ha}^{-1}\right)\end{array}$ \\
\hline (Gelong ni) & $108.91 \mathrm{a}$ & 6.17 & 4.82 & 21.13 & 92.44 & $16.18 a$ & 2.1 & 2.97 \\
\hline (Gelong se) & $99.54 \mathrm{~b}$ & 6.64 & 5.22 & 20.90 & 91.29 & $15.63 b$ & 2.3 & 2.73 \\
\hline Level of sig. & $*$ & NS & NS & NS & NS & $*$ & NS & NS \\
\hline
\end{tabular}

In a column, figures with same letter or without letter do not differ significantly whereas figures with dissimilar letters differ significantly as per DMRT; ${ }^{*}=$ Significant at $5 \%{ }^{* *}=$ Significant at $1 \% \quad$ NS $=$ Non-significant.

Table 3. Interaction effect of variety and planting dates on crop characters, yield and yield contributing characters of rice cultivars for Aman (summer) season in plain land environment.

\begin{tabular}{|c|c|c|c|c|c|c|c|c|}
\hline $\begin{array}{l}\text { Interaction } \\
\text { (variety } \times \text { planting date) }\end{array}$ & $\begin{array}{l}\text { Plant } \\
\text { height } \\
(\mathrm{cm})\end{array}$ & $\begin{array}{c}\text { No. of } \\
\text { total } \\
\text { tillers hill- }\end{array}$ & $\begin{array}{l}\text { No. of } \\
\text { effective } \\
\text { tillers hill- }\end{array}$ & $\begin{array}{c}\text { Panicle } \\
\text { length } \\
\text { (cm) }\end{array}$ & $\begin{array}{l}\text { No. of } \\
\text { grains } \\
\text { panicle }^{-1}\end{array}$ & $\begin{array}{c}1000 \\
\text { grain } \\
\text { weight }(g)\end{array}$ & $\begin{array}{l}\text { Grain } \\
\text { yield } \\
\left(\mathrm{t} \mathrm{ha}^{-1}\right)\end{array}$ & $\begin{array}{c}\text { Straw } \\
\text { yield } \\
\left(\mathrm{t} \mathrm{ha}^{-1}\right)\end{array}$ \\
\hline $\mathrm{V}_{1} \times \mathrm{D}_{1}$ & $133.87 a$ & 6.40 bcde & 5.20 cde & 23.28ab & $142.65 a$ & 16.83 & $3.37 \mathrm{~b}$ & $4.10 \mathrm{a}$ \\
\hline $\mathrm{V}_{1} \times \mathrm{D}_{2}$ & $130.93 a$ & $7.73 a b$ & 6.53ab & $23.56 a$ & $128.15 a$ & 16.81 & $3.8 \mathrm{ab}$ & $2.63 c$ \\
\hline $\mathrm{V}_{1} \times \mathrm{D}_{3}$ & $114.60 \mathrm{~b}$ & $5.60 \mathrm{cdef}$ & $4.73 \mathrm{def}$ & $22.72 \mathrm{ab}$ & $108.25 b$ & 16.80 & $2.33 c$ & $2.27 c$ \\
\hline $\mathrm{V}_{1} \times \mathrm{D}_{4}$ & $96.67 \mathrm{c}$ & $5.27 \mathrm{def}$ & $4.13 \mathrm{efg}$ & $19.81 \mathrm{c}$ & $74.51 \mathrm{c}$ & 16.66 & $1.39 \mathrm{~d}$ & $3.94 \mathrm{ab}$ \\
\hline $\mathrm{V}_{1} \times \mathrm{D}_{5}$ & $95.60 \mathrm{c}$ & $7.00 \mathrm{bcd}$ & $4.33 \mathrm{efg}$ & $19.27 \mathrm{~cd}$ & $56.57 \mathrm{~cd}$ & 16.45 & $1.08 \mathrm{de}$ & $2.53 c$ \\
\hline$V_{1} \times D_{6}$ & $81.80 \mathrm{~d}$ & 4.99 ef & $3.99 \mathrm{fg}$ & $18.11 \mathrm{de}$ & $44.49 d$ & 13.51 & 0.65 ef & $2.32 \mathrm{c}$ \\
\hline $\mathrm{V}_{2} \times \mathrm{D}_{1}$ & $128.20 \mathrm{a}$ & $7.40 \mathrm{abc}$ & $6.27 \mathrm{abc}$ & 23.38ab & $143.13 a$ & 16.80 & $4.03 \mathrm{a}$ & $2.97 \mathrm{bc}$ \\
\hline $\mathrm{V}_{2} \times \mathrm{D}_{2}$ & $131.07 \mathrm{a}$ & $9.00 \mathrm{a}$ & $7.20 \mathrm{a}$ & $23.49 a$ & $131.46 a$ & 16.79 & $4.3 a$ & $2.82 \mathrm{c}$ \\
\hline $\mathrm{V}_{2} \times \mathrm{D}_{3}$ & $111.93 b$ & 6.93 bcde & $5.73 \mathrm{bcd}$ & $22.09 \mathrm{~b}$ & $95.57 \mathrm{~b}$ & 16.79 & $2.5 c$ & $2.19 c$ \\
\hline $\mathrm{V}_{2} \times \mathrm{D}_{4}$ & $87.40 \mathrm{~d}$ & 6.00 bcde & $4.67 \mathrm{def}$ & $19.59 c$ & $72.51 \mathrm{c}$ & 16.50 & $1.51 \mathrm{~d}$ & $4.13 a$ \\
\hline $\mathrm{V}_{2} \times \mathrm{D}_{5}$ & $69.73 \mathrm{e}$ & 6.53 bcde & $4.13 \mathrm{efg}$ & $19.20 \mathrm{~cd}$ & $64.21 \mathrm{c}$ & 16.33 & $1.14 \mathrm{de}$ & $2.25 \mathrm{c}$ \\
\hline $\mathrm{V}_{2} \times \mathrm{D}_{6}$ & $68.88 \mathrm{e}$ & $4.00 \mathrm{f}$ & $3.33 \mathrm{~g}$ & $17.62 \mathrm{e}$ & $40.86 d$ & 10.56 & $0.39 f$ & $2.03 c$ \\
\hline Level of sig. & $*$ & $*$ & $*$ & $*$ & $*$ & * & * & $*$ \\
\hline
\end{tabular}

In a column, figures with same letter or without letter do not differ significantly whereas figures with dissimilar letters differ significantly as per DMRT; ${ }^{*}=$ Significant at 5\%, ${ }^{* *}=$ Significant at 1\%, NS=Non-significant; D1: 20 July, D2: 5 August; D3: 20 August; D4: 5 September; D5: 20 September; D6: 5 October; V1: Gelong ni: V2: Gelong se.

Yield contributing characters and yield

Effect of planting date on yield contributing characters and yield is presented in table 1 and effect of varieties is presented in table 2. Number of effective tillers was significantly affected by date of planting and interaction between date of planting and varieties with $5 \%$ level of significance. Varieties did not exert any significant difference on number of effective tillers. Highest number of total tillers (6.87) was found when the rice plant was transplanted at August 5. Considering interaction, highest total tillers (7.20) was observed when the variety Gelong se was transplanted on August 05 (Table 3). Number of grains spike ${ }^{-1}$ was significantly affected by date of planting and interaction between date of planting and varieties with $5 \%$ level of significance. Varieties did not show any significant difference on number of grains spike ${ }^{-1}$. Statistically the maximum number of grains spike $^{-1}$ (142.89) was found when the rice plant was transplanted on July 20 which was followed by the number of grains spike ${ }^{-1}$ (129.8) obtained when the rice plant was transplanted on August 05. Considering interaction, the maximum number of grains spike ${ }^{-1}$ was found in both of the varieties when transplanted on July 20 followed by August 05. 
Weight of 1000-grain was significantly affected by date of planting and varieties with $5 \%$ level of significance but did not show significant difference by interaction. The highest 1000grain weight was observed in case of variety Gelong ni and considering date of planting the lowest 1000-grain weight was observed when the rice plant was transplanted on October 20 , otherwise all the other date of planting exerted similar results that means statistically highest 1000-grain weight, though numerically highest 1000 -grain weight was observed when the rice variety was transplanted in July 20 (16.82 g). Grain yield was significantly affected by date of planting and interaction between date of planting and varieties with $5 \%$ level of significance. Varieties did not show any significant difference on grain yield $\left(\mathrm{t} \mathrm{ha-}{ }^{1}\right)$. The highest grain yield $\left(4.00 \mathrm{t} \mathrm{ha}^{-1}\right)$ was obtained when the crop was transplanted on August 05 and which was statistically at par with July 20. In case of interaction effect, statistically highest grain yield $\left(4.3 \mathrm{t} \mathrm{ha}^{-1}\right)$ was obtained when variety Gelong se was transplanted on August 05.

Straw yield was significantly affected by date of planting and interaction between date of planting and varieties with $5 \%$ level of significance. Varieties did not show any significant difference on straw yield $\left(\mathrm{t} \mathrm{ha}^{-1}\right)$. The highest straw yield $\left(4.7 \mathrm{t} \mathrm{ha}^{-1}\right)$ was obtained when the crop was transplanted on August 05 and which was statistically at par with July 20 . In case of interaction effect, statistically highest straw yield $\left(4.8 \mathrm{t} \mathrm{ha}^{-1}\right)$ was obtained when variety Gelong se was transplanted on August 05.

Experiment two (Response to NPKS fertilizers of two black rice cultivars)

\section{Crop characteristics}

Plant height was significantly affected by rice varieties and fertilizer dose with $5 \%$ level of significance. Tallest plant (145.90 $\mathrm{cm}$ ) was obtained from Nizershail rice variety (Table 4). Considering the fertilizer dose, tallest plants $(119.7 \mathrm{~cm})$ were observed when $100 \%$ of the recommended dose of fertilizer was applied which was statistically at par with 125\% RD (Table 5). Interaction effect on plant height was also significant at $5 \%$ level of significance and it was observed that tallest plant height $(152.6 \mathrm{~cm})$ was obtained with the variety Nazirshail when applied with $75 \%$ RD of fertilizer which was statistically similar $(150.2 \mathrm{~cm})$ with that of same when $100 \%$ RD of fertilizer was applied. Number of total tillers was significantly affected by varieties and interaction between varieties and fertilizer dose with $5 \%$ level of significance. Considering only fertilizer dose, it did not exert any significant difference on total tillers. Highest number of total tillers (8.3) was found in rice cultivar Nizershail. Considering interaction, highest total tillers (9.3) was observed when the variety Gelong se was transplanted with $100 \%$ RD of fertilizers.

Table 4. Effect of varieties on crop characters, yield parameters and yield of rice

\begin{tabular}{|c|c|c|c|c|c|c|c|c|}
\hline Varieties & $\begin{array}{l}\text { Plant } \\
\text { height } \\
(\mathrm{cm})\end{array}$ & $\begin{array}{c}\text { No. of } \\
\text { total } \\
\text { tillers }\end{array}$ & $\begin{array}{c}\text { No. of } \\
\text { effective } \\
\text { tillers }\end{array}$ & $\begin{array}{c}\text { Panicle } \\
\text { length } \\
(\mathrm{cm})\end{array}$ & $\begin{array}{c}\text { No. of } \\
\text { grains } \\
\text { panicle }^{-1}\end{array}$ & WTS (g) & $\begin{array}{l}\text { Grain } \\
\text { Yield } \\
\left(\text { tha }^{-1}\right)\end{array}$ & $\begin{array}{c}\text { Straw } \\
\text { Yield } \\
\left(\text { tha }^{-1}\right)\end{array}$ \\
\hline Kongnam ene & $86.23 c$ & $7.9 \mathrm{a}$ & $6.2 a b$ & $25.4 a$ & $122.7 \mathrm{a}$ & $20.25 c$ & $3.3 b$ & $4.5 c$ \\
\hline Gelong se & $119.1 b$ & $6.9 \mathrm{~b}$ & $6.0 \mathrm{~b}$ & $23.3 b$ & $101.6 \mathrm{~b}$ & $20.84 b$ & $4.1 \mathrm{a}$ & $5.9 a$ \\
\hline Nizershail & 145.9 a & $8.3 \mathrm{a}$ & $6.6 \mathrm{a}$ & $20.7 c$ & $98.88 b$ & $21.92 \mathrm{a}$ & $3.8 \mathrm{a}$ & $5.1 b$ \\
\hline $\begin{array}{l}\text { Level of } \\
\text { significance }\end{array}$ & $* * *$ & $* * *$ & $* *$ & $* * *$ & $* * *$ & $* * *$ & $* * *$ & $* * *$ \\
\hline
\end{tabular}

In a column, figures with same letter or without letter do not differ significantly whereas figures with dissimilar letters differ significantly as per DMRT; ${ }^{* *}=$ Significant at $1 \%,{ }^{* * *}=$ Significant at $0.1 \%$, NS=Non-significant

Table 5. Effect of fertilizer dose on crop characters, yield parameters and yield of black rice cultivars

\begin{tabular}{|c|c|c|c|c|c|c|c|c|}
\hline Fertilizer dose & $\begin{array}{c}\text { Plant } \\
\text { height } \\
\text { (cm) }\end{array}$ & $\begin{array}{l}\text { No. of } \\
\text { total } \\
\text { tillers }\end{array}$ & $\begin{array}{l}\text { No. of } \\
\text { effective } \\
\text { tillers }\end{array}$ & $\begin{array}{c}\text { Panicle } \\
\text { length } \\
\text { (cm) }\end{array}$ & $\begin{array}{l}\text { No. of } \\
\text { grains } \\
\text { panicle }^{-1}\end{array}$ & WTS (g) & $\begin{array}{l}\text { Grain yield } \\
\quad\left(\text { tha }^{-1}\right)\end{array}$ & $\begin{array}{l}\text { straw } \\
\text { yield } \\
\left(\text { tha }^{-1}\right)\end{array}$ \\
\hline $\mathrm{F}_{1}$ & $112.6 \mathrm{c}$ & 7.0 & $65.4 \mathrm{~b}$ & $23.4 a b$ & $100.0 \mathrm{c}$ & $19.78 \mathrm{c}$ & $3.0 \mathrm{c}$ & $4.5 \mathrm{c}$ \\
\hline $\mathrm{F}_{2}$ & $115.9 b$ & 7.3 & $6.4 b$ & $24.7 a$ & $106.0 \mathrm{c}$ & $19.15 d$ & $3.7 \mathrm{~b}$ & $5.05 b$ \\
\hline $\mathrm{F}_{3}$ & $116.7 b$ & 7.9 & $6.0 \mathrm{~b}$ & $23.5 \mathrm{ab}$ & $118.3 \mathrm{a}$ & $21.1 b$ & $3.8 \mathrm{~b}$ & $5.0 \mathrm{~b}$ \\
\hline $\mathrm{F}_{4}$ & $119.6 \mathrm{a}$ & 8.2 & $7.0 \mathrm{a}$ & $22.7 a b$ & $120.3 \mathrm{a}$ & $21.56 b$ & $4.0 \mathrm{a}$ & $5.2 a b$ \\
\hline $\mathrm{F}_{5}$ & $118.7 \mathrm{a}$ & 7.7 & $6.8 \mathrm{a}$ & $22.9 a b$ & $121.3 \mathrm{a}$ & $21.26 b$ & $4.0 \mathrm{a}$ & $5.2 a b$ \\
\hline $\mathrm{F}_{6}$ & $117.1 \mathrm{~b}$ & 7.3 & $6.1 b$ & $21.6 b$ & 115.b & $23.17 a$ & $3.8 \mathrm{~b}$ & $5.6 \mathrm{a}$ \\
\hline $\begin{array}{l}\text { Level of } \\
\text { significance }\end{array}$ & $* * *$ & NS & $*$ & $*$ & $*$ & $* * *$ & $* *$ & $* * *$ \\
\hline
\end{tabular}

In a column, figures with same letter or without letter do not differ significantly whereas figures with dissimilar letters differ significantly as per DMRT; ${ }^{*}=$ Significant at $5 \%,{ }^{* *}=$ Significant at $1 \%,{ }^{* * *}=$ Significant at $0.1 \%$, NS=Non-significant.

\footnotetext{
$\mathrm{F}_{1}$ : $\quad$ No fertilizer

$\mathrm{F}_{2}$ : $\quad 50 \%$ recommended dose of fertilizers ( $50 \mathrm{~kg}$ urea, $20 \mathrm{~kg}$ TSP, $10 \mathrm{~kg} \mathrm{MoP}$ and $15 \mathrm{~kg}$ Gypsum)

$\mathrm{F}_{3}$ : $\quad 75 \%$ recommended dose of fertilizers ( $75 \mathrm{~kg}$ urea, $30 \mathrm{~kg}$ TSP, $15 \mathrm{~kg}$ MoP and $22.5 \mathrm{~kg}$ Gypsum)

$\mathrm{F}_{4}: \quad 100 \%$ recommended dose of fertilizers (100 kg urea, $40 \mathrm{~kg}$ TSP, $20 \mathrm{~kg}$ MoP and $30 \mathrm{~kg}$ Gypsum)

$\mathrm{F}_{5}$ : $\quad 125 \%$ recommended dose of fertilizers (125 kg urea, $50 \mathrm{~kg}$ TSP, $25 \mathrm{~kg}$ MoP and $37.5 \mathrm{~kg}$ Gypsum)

$\mathrm{F}_{6}$ : $\quad 150 \%$ recommended dose of fertilizers (150 kg urea, $60 \mathrm{~kg}$ TSP, $30 \mathrm{~kg}$ MoP and $45 \mathrm{~kg}$ Gypsum)
} 
Table 6. Interaction effect of varieties and fertilizer doses on crop characters, yield parameters and yield on some hilly black rice cultivars.

\begin{tabular}{|c|c|c|c|c|c|c|c|c|}
\hline Interaction & $\begin{array}{c}\text { Plant } \\
\text { height }(\mathrm{cm})\end{array}$ & $\begin{array}{c}\text { No. of } \\
\text { total } \\
\text { tillers }\end{array}$ & $\begin{array}{l}\text { No. of } \\
\text { effective } \\
\text { tillers }\end{array}$ & $\begin{array}{c}\text { Panicle } \\
\text { length } \\
(\mathrm{cm})\end{array}$ & $\begin{array}{l}\text { Grain no. } \\
\text { panicle }^{-1}\end{array}$ & WTS (g) & $\begin{array}{l}\text { Grain yield } \\
\left(\text { tha }^{-1}\right)\end{array}$ & $\begin{array}{l}\text { straw yield } \\
\left(\text { tha }^{-1}\right)\end{array}$ \\
\hline $\mathrm{F}_{1} \times \mathrm{V}_{1}$ & $86.5 \mathrm{hi}$ & $8.3 \mathrm{ad}$ & 6.1 be & $25.6 \mathrm{ab}$ & $98.1 d$ & $17.73 \mathrm{j}$ & $2.8 \mathrm{~g}$ & $3.7 f$ \\
\hline $\mathrm{F}_{1} \times \mathrm{V}_{2}$ & $88.6 \mathrm{~g}$ & $6.7 \mathrm{ce}$ & $5.6 \mathrm{e}$ & 23.4ad & 120.6ab & $18.5 \mathrm{ij}$ & $3.4 \mathrm{eg}$ & $4.9 \mathrm{de}$ \\
\hline $\mathrm{F}_{1} \times \mathrm{V}_{3}$ & $90.2 \mathrm{a}$ & $8.4 \mathrm{ac}$ & $6.4 \mathrm{ae}$ & 21.1ce & $99.2 d$ & $19.12 \mathrm{ab}$ & 3.9af & $5.2 \mathrm{ce}$ \\
\hline $\mathrm{F}_{2} \times \mathrm{V}_{1}$ & $110.3 \mathrm{hi}$ & $8.9 a b$ & 6.1be & $26.5 a$ & $99.8 d$ & $19.57 \mathrm{gi}$ & $3.2 \mathrm{fg}$ & $4.5 \mathrm{e}$ \\
\hline $\mathrm{F}_{2} \times \mathrm{V}_{2}$ & 118.1eg & 7.2 be & 6.4ae & $26.5 a$ & $131.4 \mathrm{a}$ & 19.03hi & 4.3ab & 6.1ab \\
\hline $\mathrm{F}_{2} \times \mathrm{V}_{3}$ & $144.4 b$ & $8.2 \mathrm{ad}$ & 6.7ad & 21.1ce & $104.2 c d$ & 18.84hi & $3.5 \mathrm{cg}$ & $4.6 \mathrm{e}$ \\
\hline $\mathrm{F}_{3} \times \mathrm{V}_{1}$ & $148.2 \mathrm{~h}$ & $8.3 \mathrm{ad}$ & 6.6ad & $23.9 \mathrm{ac}$ & $94.9 d$ & $20.63 e g$ & $3.5 \mathrm{defg}$ & $4.6 \mathrm{e}$ \\
\hline $\mathrm{F}_{3} \times \mathrm{V}_{2}$ & $117.2 \mathrm{fg}$ & $6.8 \mathrm{ce}$ & 6.1be & $25.5 a b$ & $129.2 \mathrm{a}$ & $20.96 \mathrm{de}$ & $4.2 \mathrm{ad}$ & $6.1 \mathrm{~b}$ \\
\hline $\mathrm{F}_{3} \times \mathrm{V}_{3}$ & $152.6 \mathrm{a}$ & $8.6 a b$ & 6.7ad & 21.1ce & $106.2 \mathrm{~cd}$ & 21.72ce & $4.367 a$ & $5.5 \mathrm{bcd}$ \\
\hline $\mathrm{F}_{4} \times \mathrm{V}_{1}$ & $140.1 \mathrm{j}$ & $7.6 \mathrm{ae}$ & 6.8ab & $24.6 a c$ & $101.2 d$ & 19.7fgh & $3.6 \mathrm{bf}$ & $4.9 \mathrm{de}$ \\
\hline $\mathrm{F}_{4} \times \mathrm{V}_{2}$ & $153.6 \mathrm{a}$ & $9.3 \mathrm{a}$ & $7.2 \mathrm{a}$ & 22.1be & $130.7 \mathrm{a}$ & $22.83 a b$ & $4.3 \mathrm{a}$ & 6.0abc \\
\hline $\mathrm{F}_{4} \times \mathrm{V}_{3}$ & $134.1 \mathrm{c}$ & $8.1 \mathrm{ad}$ & $5.5 \mathrm{e}$ & $21.5 c e$ & $101.7 d$ & $23.15 a b$ & $3.5 \mathrm{dg}$ & $4.6 e$ \\
\hline $\mathrm{F}_{5} \times \mathrm{V}_{1}$ & $130.9 \mathrm{ij}$ & $7.6 \mathrm{ae}$ & $5.8 \mathrm{ce}$ & $27.1 \mathrm{a}$ & $98.4 d$ & $22.15 b c$ & $3.4 \mathrm{eg}$ & $4.7 \mathrm{de}$ \\
\hline $\mathrm{F}_{5} \times \mathrm{V}_{2}$ & $120.4 \mathrm{df}$ & 7.4 be & 6.3ae & 22.3be & $115.9 b c$ & 20.86de & 4.1ae & $5.7 b c$ \\
\hline $\mathrm{F}_{5} \times \mathrm{V}_{3}$ & $150.7 \mathrm{a}$ & $8.2 \mathrm{ad}$ & $6.2 \mathrm{bc}$ & $19.3 \mathrm{e}$ & $98.8 d$ & $20.76 \mathrm{df}$ & $3.967 \mathrm{ae}$ & 5.267be \\
\hline $\mathrm{F}_{6} \times \mathrm{V}_{1}$ & $130.1 \mathrm{hi}$ & $6.6 \mathrm{de}$ & $5.9 \mathrm{be}$ & $24.7 \mathrm{ac}$ & $101.0 d$ & 21.69ce & $3.5 \mathrm{cg}$ & $4.9 \mathrm{de}$ \\
\hline $\mathrm{F}_{6} \times \mathrm{V}_{2}$ & $122.2 \mathrm{~d}$ & 6.9ce & $5.7 \mathrm{de}$ & 20.0de & $115.3 b c$ & 23.87a & $4.2 \mathrm{ac}$ & $6.6 a$ \\
\hline $\mathrm{F}_{6} \times \mathrm{V}_{3}$ & $143.1 b$ & $8.3 \mathrm{ad}$ & $6.8 a c$ & 20.1de & $99.5 d$ & $23.94 a$ & $4.0 \mathrm{~b}$ & $5.7 b c$ \\
\hline $\begin{array}{l}\text { Level of } \\
\text { significance }\end{array}$ & $* * *$ & * & * & * & * & $* * *$ & * & * \\
\hline
\end{tabular}

In a column, figures with same letter or without letter do not differ significantly whereas figures with dissimilar letters differ significantly as per DMRT. ${ }^{*}=$ Significant at $5 \%,{ }^{* *}=$ Significant at $1 \%,{ }^{* * *}=$ Significant at $0.1 \%$, NS=Non-significant.

$\begin{array}{ll}\mathrm{F}_{1}: & \text { No fertilizer } \\ \mathrm{F}_{2}: & 50 \% \text { recommended dose of fertilizers } \\ \mathrm{F}_{3}: & 75 \% \text { recommended dose of fertilizers } \\ \mathrm{F}_{4}: & 100 \% \text { recommended dose of fertilizers } \\ \mathrm{F}_{5}: & 125 \% \text { recommended dose of fertilizers } \\ \mathrm{F}_{6}: & 150 \% \text { recommended dose of fertilizers }\end{array}$

Panicle length was significantly affected by varieties, fertilizer dose and with their interaction at $5 \%$ level of significance. Statistically the longest panicle $(25.4 \mathrm{~cm})$ was found from the variety Kongnam ene. Considering interaction, longest panicle was observed when Kongnam ene was transplanted with $125 \%$ RD of fertilizers. All the interaction effects have been presented in Table 6.

\section{Yield contributing characters and yield}

Number of effective tillers was significantly affected by varieties, fertilizer dose and interaction between varieties and fertilizer dose with $5 \%$ level of significance (Table 4, 5 and 6). Considering individual factor effect, highest number of effective tillers (6.6) were found from Nizershail rice cultivar and with $100 \%$ RD of fertilizer application (7.0). Considering interaction, highest total tillers (7.2) was observed when the variety Gelong se was cultivated with $100 \%$ RD of fertilizers. Number of grains spike $^{-1}$ was significantly affected by varieties, fertilizer dose and with their interaction at $5 \%$ level of significance. Considering individual effect, statistically highest number of grains spike ${ }^{-1}$ was found from the variety Kongnam ene (122.7) and when $125 \%$ RD of fertilizers were applied. Considering the interaction effect, maximum number of grains spike ${ }^{-1}$ was observed (129.2) when the variety Gelong se was transplanted with $75 \%$ RD of fertilizers. Weight of 1000-grain was significantly affected by variety, fertilizer dose and also by interaction between them at
$0.1 \%$ level of significance. The highest 1000 -grain weight was observed in case of variety Nizershail (21.92 g). In case of fertilizer dose, the highest 1000-grain weight was found when the crop field was fertilized with $150 \%$ RD of fertilizers. Considering the interaction effect, highest grain weight was found when Nizershail was cultivated with $150 \%$ RD of fertilzers.

Grain yield was significantly affected by varietal difference with $0.1 \%$ level of significance while it was affected by fertilizer dose at $1 \%$ level of significance. The highest grain yield $\left(4.1 \mathrm{t} \mathrm{ha}^{-1}\right)$ was obtained from the variety Gelong se. Considering fertilizer dose, the highest grain yield $\left(4.0 \mathrm{t} \mathrm{ha}^{-1}\right)$ was found when the field was fertilized with $100 \%$ RD of fertilizers. The grain yield was also affected by interaction between variety and fertilizers with $5 \%$ level of significance. It was found that significantly highest grain yield ( $4.3 \mathrm{t} \mathrm{ha}^{-1}$ ) was obtained when Gelong se was fertilized with $100 \%$ RD of fertilizer. Straw yield was significantly affected by varietal difference and fertilizer dose with $0.1 \%$ level of significance. The highest straw yield $\left(5.9 \mathrm{t} \mathrm{ha}^{-1}\right)$ was obtained from the variety Gelong se. Considering fertilizer dose, the highest straw yield $\left(5.6 \mathrm{t} \mathrm{ha}^{-1}\right)$ was found when the field was fertilized with $150 \%$ RD of fertilizers. The straw yield was also affected by interaction between variety and fertilizers with $5 \%$ level of significance. It was found that significantly highest straw yield $\left(6.6 \mathrm{t} \mathrm{ha}^{-1}\right.$ ) was obtained when Gelong se was fertilized with $150 \%$ RD of fertilizer. 


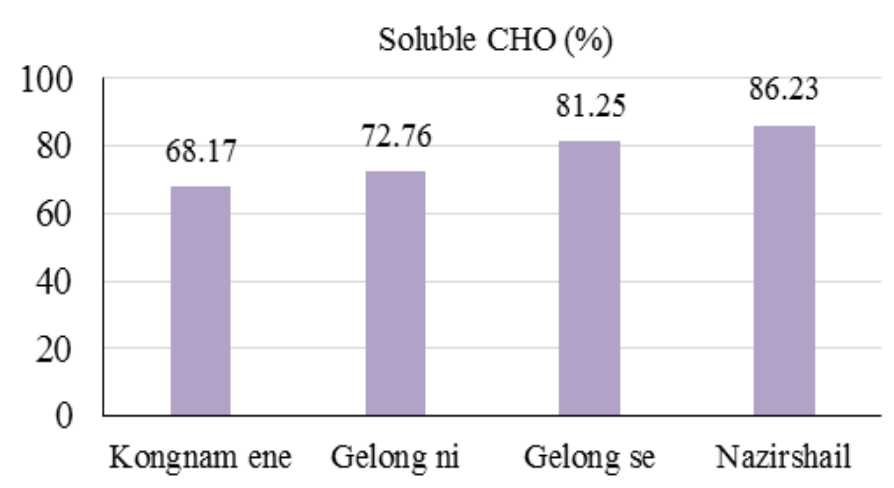

a

Rice culitvars

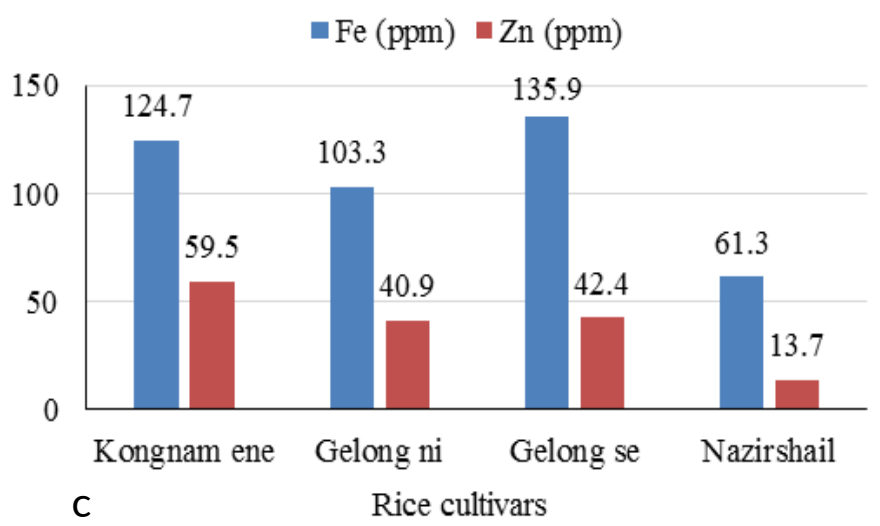

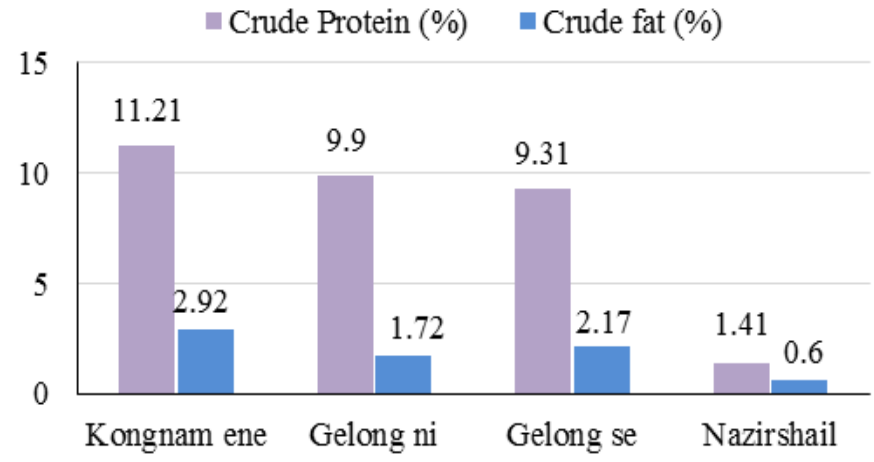

b

Rice cultivars

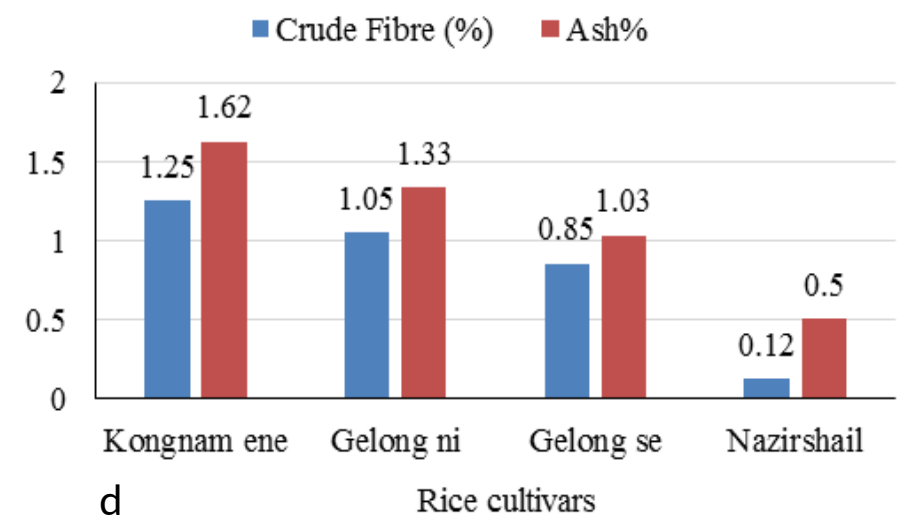

Figure 1 (a-d). Nutritional value (soluble CHO, crude protein, crude fat, Fe, Zn, crude fibre and ash content) of different black rice and white rice cultivars.

Nutrient contents of Black rice compared to white rice

Nutrient contents of three black rice cultivars were compared with one popular white rice local cultivar named nazirshail (Figure 1a-d). It was found that the carbohydrate content was found highest in nazirshail rice (86.23\%) and lowest in kongnam ene (68.17\%). Crude protein (11.21\%) and crud fat (2.92\%) was found higher in the black rice cultivar kongnam ene compared to other rice cultivars and lowest crude protein (1.41\%) and crude fat (0.6\%) was found in nazirshail rice. In case of Fe content, the highest amount of Fe (135.9 ppm) was found in the black rice cultivar gelong se and the lowest amount of $\mathrm{Fe}(61.3 \mathrm{ppm})$ was found in the local white rice cultivar nazirshail. Similar pattern was also found in case of $\mathrm{Zn}$ content. The highest (59.5 ppm) and lowest (13.7 $\mathrm{ppm}$ ) amount of $\mathrm{Zn}$ was found in kongnam ene and nazirshail rice cultivar, respectively. Highest amount of crude fibre (1.25\%) and ash (1.62\%) was observed in the black rice cultivar kongnam ene and the lowest amount of crude fibre (0.12\%) and ash (0.5\%) was observed in case of the white rice cultivar nazirshail.

\section{Conclusion}

Based on the findings of the two experiments the following conclusion may be made: Among varieties, the black rice cultivar Gelong se considered best grain yielding potential variety than three other rice varieties, of which two are black rice cultivars (Kongnam ene and Gelong ne) and another one is plain land white rice cultivar (Nizershail). Regarding time of transplanting it has been revealed that all the varieties gave higher yield when they were transplanted either on July 20 or August 05. The worst transplanting time was October 5 when lowest grain yield was obtained. This might be due to the photosensitive characteristic of the varieties. When the varieties were transplanted on July 20 or August 05 they get sufficient time to get their vegetative growth and produce maximum dry matter. But, when the transplanting time is delayed then the varieties did not get enough time for vegetative growth before flowering. Therefore, late transplanting resulted lowest yield. For having maximum grain yield provision of fertilizer to the soil is a must. From the results it has been found that $100 \%$ recommended dose of fertilizer for a local plain land white rice cultivar gave highest yield for all of the black rice cultivars. This means the hilly black rice cultivar responded to the fertilizer as the plain land local rice cultivar respond. Therefore, finally it could be concluded that black rice cultivar Gelong se can be cultivated in plain land environment if it is transplanted either on Jul 20 or August 05 with a fertilizer dose of $100 \mathrm{~kg}$ urea, $40 \mathrm{~kg}$ TSP, $20 \mathrm{~kg} \mathrm{MoP}$ and $30 \mathrm{~kg}$ Gypsum. Considering the nutritional fact, either of the black rice cultivar is more preferable than that of the white rice cultivar.

\section{ACKNOWLEDGEMENT}

The authors greatly acknowledge the Ministry of Science and Technology (MoST-39.00.0000.09.02.069.16-17/11/55/BS277) Peoples Republic of Bangladesh for providing financial support to conduct the research work.

Open Access: This is an open access article distributed under the terms of the Creative Commons Attribution 4.0 License, which permits unrestricted use, distribution, and reproduction in any medium, provided the original author(s) if the sources are credited. 


\section{REFERENCES}

Abdel-Aal E.S.M., Young, J.C. and Rabalski, I. (2006). Anthocyanin composition in black, blue, pink, purple and red cereal grains. Journal of Agricutlure and Food Chemistry, 54: 4696-4704.

BBS (Bangladesh Bureau of Statistics). (2017). Statistical pocket book of Bangladesh. Bureau of Statistics, Statistics Division, Ministry of planning, Government of the People's Republic of Bangladesh, pp. 34, 39.

BBS (Bangladesh Bureau of Statistics). (2018). Statistical Pocketbook of Bangladesh Statistic Division. Government of the People's Republic of Bangladesh. Retrieved from http://www.bbs.gov.bd

Chaudhary, R.C. (2003). Speciality rices of the world: Effect of WTO and IPR on its production trend and marketing. Journal of Food Agriculture and Environment, 1(2): 34-41.

Han, S.J., Ryu, S.N. and Kang, S.S. (2004). A new 2-arylbenzofuran with antioxidant activity from the black colored rice (Oryza sativa L.) bran. Chemical and Pharmaceutical Bulletin, 52:1365-1366

Ichikawa, H., Ichiyanagi, T., Xu, B., Yoshii, Y., Nakajima, M. and Konishi, T. (2001). Antioxidant activity of anthocyanin extract from purple black rice. Journal of Medical Food, 4(4): 211-218.
Kong, L., Wang, Y. and Cao, Y. (2008). Determination of Myo-inositol and D-chiroinositol in black rice bran by capillary electrophoresiswith electrochemical detection. Journal of Food Composition and Analysis, 21 (6): 501-504.

Nam, S.H., Choi, S.P., Kang, M.Y., Koh, H.J., Kozukue, N. and Friedman, M. (2006). Antioxidative activities of bran extracts from twenty one pigmented rice cultivars. Food Chemistry, 94(4): 613-620.

Ryu, S.N., Park, S.Z., Ho, C.T. (1998). High performance liquid chromatographic determination of anthocyanin pigments in some varieties of black rice. Journal of Food Drug Analysis, 6(4): 729-736.

Ryu, S.N., Park, S.Z., Kang, S.S., Lee, E.B. and Han, S.J. (2000). Food safety of pigment in black rice cv. Heugjinjubyeo. Korean Journal of Crop Science, 45: 370-373.

Sompong, R., Siebenhandl, E.S., Linsberger, M.G. and Berghofer, E. (2011). Physicochemical and antioxidative properties of red and black rice varieties from Thailand, China and Sri Lanka. Food Chemistry, 124(1): 132-140.

Yao, S. L., Xu, Y., Zhang, Y. Y. and Lu, Y. H. (2013). Black rice and anthocyanins induce inhibition of cholesterol absorption in vitro. Food and Function, 4 (11): 1602-1608, https://dx.doi.org/10.1039/c3fo60196j

Yawadio, R., Tanimori, S. and Morita, N. (2007). Identification of phenolic compounds isolated from pigmented rices and their aldose reductase inhibitory activities. Food Chemistry, 101: 1616-1625. 